\title{
STUDI POTENSI EKSTRAK DAUN ADAM HAWA (Rhoeo discolor) SEBAGAI INDIKATOR TITRASI ASAM-BASA
}

\author{
Sinta Ratnasari*, Dede Suhendar, Vina Amalia \\ Jurusan Kimia, Fakultas Sains dan Teknologi, Universitas Islam Negeri Sunan Gunung Djati, Jalan A.H. \\ Nasution No. 105 Bandung 40614 \\ *Alamat Korespondensi: sinta.ratnasari19@gmail.com
}

\begin{abstract}
Abstrak: Daun adam hawa memiliki pigmen warna ungu yang diduga berasal dari antosianin. Pigmen antosianin ini bersifat larut dalam air sehingga mampu bereaksi baik dengan asam maupun basa. Karakterisitik perubahan warna ini menjadi potensi ekstrak daun adam hawa sebagai indikator dalam menentukan titik akhir pada titrasi asam basa. Perbandingan pelarut etanol 70\% : ekstrak daun adam hawa (2:1) mampu mengekstrak metabolit sekunder secara optimal dengan metode ekstrasi teknik maserasi selama 24 jam. Karakterisasi indikator ini meliputi uji perubahan warna dalam berbagai $\mathrm{pH}$, titrasi asam basa konvensional dan autotitrator, perbandingannya dengan indikator fenolftalein (PP) dan metil jingga (MJ), identifikasi menggunakan spektrofotometer sinar tampak dan FTIR serta uji waktu simpan indikator. Hasil karakterisasi menunjukkan, indikator memiliki perubahan warna dari jingga kemerahan-hijau kecoklatan dengan trayek pH 4,75-6,75 pada daerah serapan $\lambda$ maksimum 510,01-591,99 nm, memiliki persentase selisih dengan indikator PP sebesar $0,915 \%$ dan indikator MJ sebesar $0,925 \%$, serta dapat digunakan sampai empat minggu.
\end{abstract}

Kata kunci: indikator, titrasi asam basa; trayek $\mathrm{pH}$; antosianin.

\begin{abstract}
Adam hawa leaf has purple pigment that comes from anthocyanin. Anthocyanin pigment is soluble in water so it can react with acid or base substances. Color change in different $p H$ value made this leave extract can be used as an indicator to determine end point of acid-base titration. Comparison of 70\% ethanol: adam hawa leaf extract (2: 1) capable of extracting secondary metabolites optimally with maceration techniques for 24 hours. Characterization of indicator include tests color changes at various $p H$ level, acid-base titration using conventional titration and autotitrator methods, comparison with phenolphthalein (PP) and methyl orange (MJ) indicator, identification using visible and FTIR spectrophotometer and retention time of indicator. Results showed, the indicator color changed from reddish orange to brownish green with pH stretch of 4.75 6.75 with maximum wavelength of 510.01-591.99 nm, has 0.915 and $0.925 \%$ difference with PP and MJ, respectively. The indicator can be used up to four weeks.
\end{abstract}

Keywords: indicators; acid-base titration; $p H$ stretch; anthocyanin.

\section{PENDAHULUAN}

Daun adam hawa (Rhoeo discolor) merupakan tanaman yang mudah dijumpai di Indonesia. Pigmen merah dan pigmen hijau yang menjadi ciri khas dari tumbuhan tersebut dihasilkan dari senyawa flavonoid yaitu antosianin dan pigmen klorofil (Kadir, 2008).

Senyawa yang berperan dalam perubahan warna indikator alami adalah antosianin yang juga merupakan metabolit sekunder golongan flavonoid dan termasuk pigmen yang larut dalam air secara alami sehingga memiliki kemampuan untuk bereaksi baik dengan asam maupun dengan basa. Antosianin berwarna merah dalam media asam, dan berubah menjadi ungu dan biru pada media basa (Winarno, 1992).

Titrasi asam basa merupakan salah satu metode analisis kuantitatif untuk menentukan konsentrasi dari suatu zat yang ada dalam larutan. Keberhasilan dalam titrasi asam-basa sangat ditentukan oleh kinerja indikator yang mampu menunjukkan titik akhir dari titrasi. Indikator merupakan suatu zat yang ditambahkan ke dalam larutan sampel sebagai penanda yang menunjukkan telah terjadinya titik akhir titrasi pada analisis volumetrik. Suatu zat dapat dikatakan sebagai indikator titrasi asam basa jika dapat memberikan perubahan warna sampel seiring dengan terjadinya perubahan konsentrasi ion hidrogen atau perubahan $\mathrm{pH}$ (Day \& Underwood, 1986).

Indikator asam basa yang sering digunakan di laboratorium untuk titrasi asam basa merupakan indikator sintetis contohnya fenolftalein (PP) dan metil jingga (MJ). Setiap indikator sintetis memiliki harga yang cukup mahal, serta dapat menyebabkan polusi lingkungan. Harga indikator titrasi asam basa yang mahal membuat terbatasnya percobaan titrasi tersebut terutama di sekolah-sekolah yang berada jauh dari perkotaan.

Kandungan antosianin yang terdapat pada daun adam hawa menyimpan potensi besar sebagai indikator titrasi asam basa.

Ekstraksi menggunakan teknik maserasi yang merupakan metode yang paling umum digunakan untuk memisahkan kandungan senyawa kimia pada jaringan tumbuhan. Etanol $70 \%$ merupakan pelarut yang baik untuk ekstraksi flavonoid khususnya 
antosianin karena memiliki sifat polar yang mampu melarutkan senyawa polar.

Dengan demikian studi penelitian dari potensi ekstrak daun adam hawa ini diharapkan dapat memberikan sumbangsih dalam ilmu kimia tingkat dasar khususnya untuk praktikum titrasi asam basa. Indikator alami dapat dijadikan sebagai bahan alternatif indikator yang mudah didapatkan dengan perbandingan biaya yang jauh lebih hemat dibandingkan dengan indikator sintetis, namun tetap memiliki manfaat dan tujuan yang sama untuk titrasi asam basa pada umumnya.

\section{BAHAN DAN METODE}

Bahan yang digunakan yaitu etanol $70 \%$ (CV. Brataco) sebagai pelarut ekstraksi, natrium hidroksida (99\%, Merck), asam klorida (36\%, Merck) dan asam oksalat dihidrat (99,5\%, Merck) digunakan dalam titrasi. Bahan lain yang digunakan yaitu akuades komersial, indikator fenolftalein (Merck) dan indikator metil jingga (Merck).

Alat-alat yang digunakan meliputi alat-alat gelas yang umum digunakan di laboratorium, blender, neraca analitik, pH-meter, dan kertas saring (Whatman 40), spektrofotometer UV-Vis untuk pengujian panjang gelombang maksimum antara 370 $-780 \mathrm{~nm}$, spektrofotometer FTIR untuk mengidentifikasi gugus fungsi dan autotitrator untuk menentukan titik ekuivalen titrasi.

\section{Preparasi sampel}

Daun adam hawa dibersihkan dengan air mengalir untuk menghilangkan kotoran yang menempel, kemudian semua sampel dipotong tipis lalu dihaluskan dengan blender selama 15-20 detik.

\section{Pembuatan ekstrak}

Daun adam hawa (AH) diekstraksi menggunakan teknik maserasi menggunakan etanol $70 \%$. Perbandingan yang digunakan antara etanol $70 \%$ dan daun adam hawa $(2: 1)$. Kemudian daun adam hawa dimasukkan ke dalam beaker glass lalu tambahkan pelarut etanol $70 \%$ sebanyak $100 \mathrm{~mL}$, selanjutnya campuran didiamkan selama 24 jam dan disaring untuk memperoleh ekstrak. Ekstrak tersebut disimpan dalam botol gelap dan suhu ruangan serta disimpan di lemari es untuk pengawetan ekstrak selama 1 bulan.

Uji warna ekstrak dari sampel dalam berbagai pH Sebanyak 10 tetes sampel ekstrak dimasukkan ke dalam $5 \mathrm{~mL}$ larutan $\mathrm{pH}$ 1-10 dan diamati perubahan warna yang terjadi. Setelah diketahui perbedaan warna secara kasat mata yang menunjukkan kemungkinan trayek $\mathrm{pH}$, maka dibuat kembali larutan $\mathrm{pH} \pm 0,5$ dari $\mathrm{pH}$ yang sebelumnya menunjukkan perubahan warna yang signifikan.

\section{Pengujian dengan Spektofotometer UV-Vis}

Sampel ekstrak dalam berbagai $\mathrm{pH}$ dan ekstrak yang disimpan selama empat minggu ditentukan panjang gelombang maksimal setiap sampel menggunakan spektrofotometer UV-Vis dengan pengukuran 1 kali seminggu pada panjang gelombang 378-780 $\mathrm{nm}$.

\section{Pengujian dengan FTIR}

Sampel ekstrak dikeringkan dengan cara dipanaskan pada suhu $40^{\circ} \mathrm{C}$ dengan penambahan etanol absolut selama 3 hari, diperoleh ekstrak kering. Ekstrak kering ditambahkan pelet $\mathrm{KBr} \pm 1 \mathrm{mg}$, kemudian dianalisis menggunakan FTIR pada bilangan gelombang $400-4000 \mathrm{~cm}^{-1}$.

\section{Uji waktu simpan dan aplikasi indikator}

Ekstrak disimpan $20 \mathrm{~mL}$ dalam botol gelap yang diberi label 1-4 yang menandakan penyimpanan selama empat minggu dengan pengecekan warna, $\mathrm{pH}$ dan pengujian kelayakan indikator dengan titrasi asam basa konvensional setiap 1 minggu sekali.

Selanjutnya, dilakukan titrasi asam basa $(\mathrm{HCl} \mathrm{0,1}$ $\mathrm{N}$ dan $\mathrm{NaOH} 0,1 \mathrm{~N}$ ) dengan menggunakan sampel indikator dan dibandingkan dengan indikator sintetis, serta dilakukan titrasi dengan autotitrator.

\section{HASIL DAN PEMBAHASAN}

\section{Hasil ekstraksi sampel perubahan warna sampel indikator}

Proses penghalusan pada daun adam hawa dilakukan untuk memperluas permukaan, sehingga mempercepat proses ekstraksi.

Pelarut etanol $70 \%$ digunakan pada proses ekstraksi, karena merupakan pelarut polar yang dapat menarik komponen yang bersifat polar yaitu antosianin.

Ekstrak sampel dapat dilihat pada Gambar 1. Warna yang dihasilkan oleh sampel ekstrak adalah warna ungu pekat.

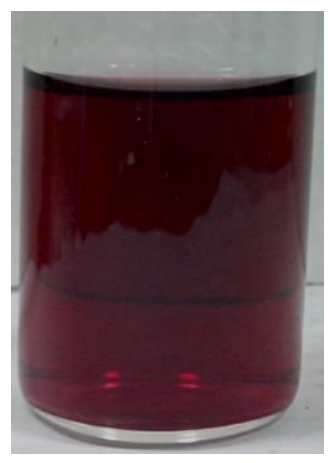

Gambar 1. Ekstrak daun adam hawa

Pada ekstrak sampel kemudian dilakukan pengujian warna dalam berbagai $\mathrm{pH}$, hal ini dilakukan untuk mengetahui sejauh manakah perubahan warna yang dihasilkan sampel dalam rentang $\mathrm{pH}$ tertentu dan perubahan warna signifikan yang dapat menunjukkan kemungkinan trayek $\mathrm{pH}$ sampel ekstrak indikator. Larutan $\mathrm{pH}$ yang digunakan 
dalam penelitian ini adalah campuran dari larutan $\mathrm{HCl}$ dan $\mathrm{NaOH}$ yang dibuat dari $\mathrm{pH} 1-10$. Larutan untuk masing-masing $\mathrm{pH}$ dibuat dengan mencampurkan larutan $\mathrm{HCl}$ dan $\mathrm{NaOH}$ sampai diperoleh $\mathrm{pH}$ yang diinginkan. Ekstrak sampel diteteskan ke dalam larutan $\mathrm{pH}$ dan dapat dilihat perubahan warnanya pada Gambar 2.

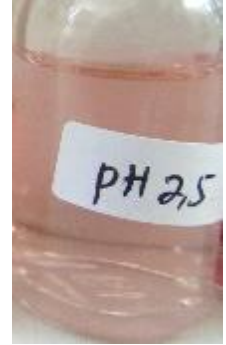

(1)

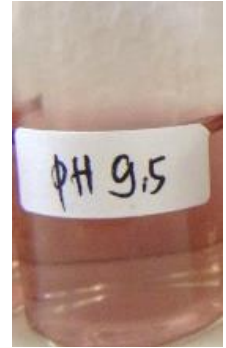

(3)

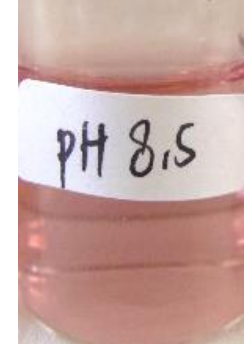

(2)

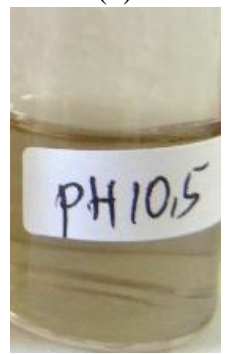

(4)
Gambar 2. Perubahan warna sampel indikator pada berbagai pH (1,2) jingga kemerahan, (3-9) ungu, (10) hijau kecoklatan

Berdasarkan hasil pengamatan, indikator daun adam hawa memiliki perubahan warna yang teramati pada $\mathrm{pH}$ 1,3-2,0 menunjukkan warna jingga, pada $\mathrm{pH}$ 3-7 berubah menjadi warna ungu, pada $\mathrm{pH}$ 8-9 warna ungu menjadi berkurang dan pada $\mathrm{pH} 10$ warna berubah menjadi hijau kecoklatan. Untuk dapat mengamati perubahan warna ini dengan akurat, maka dibuat larutan $\mathrm{pH}$ dengan rentang 0,5 dari $\mathrm{pH}$ sebelumnya yang mengalami perubahan warna yang signifikan. Hasil pengujian dapat dilihat pada Gambar 3.

Sampel indikator daun adam hawa memberikan warna yang sama dari $\mathrm{pH} 2,5 ; 8,5$ dan 9,5 yaitu warna ungu muda, tetapi pada $\mathrm{pH} 10,5$ warna yang ditujukkan adalah hijau kecoklatan yang lebih terlihat jelas dari $\mathrm{pH}$ sebelumnya yaitu $\mathrm{pH} 10$.

\section{Hasil analisis menggunakan spektrofotometer UV-Vis}

Antosianin memiliki absorbansi maksimum pada panjang gelombang 475-560 nm, sedangkan pada sampel indikator daun adam hawa terlihat pada Gambar 4. terdapat dua puncak pada panjang gelombang 540-610 nm. Panjang gelombang maksimum dari suatu zat berbeda-beda bergantung pada mudah atau tidaknya terjadi eksitasi elektron. Hal ini juga dapat dilihat dari kepekatan warnanya, karena absorbansi dari suatu zat bergantung pada struktur elektronik senyawa dan kepekatan dari sampel yang pada akhirnya menentukan konsentrasi dari sampel tersebut.

Penentuan panjang gelombang maksimum dari sampel indikator dapat dilihat dari warna yang dapat dilihat secara kasat mata (warna komplementer) dan dibandingkan dengan warna yang diserap serta panjang gelombangnya dalam literatur. Pada sampel indikator daun adam hawa warna yang dihasilkan adalah warna ungu maka yang diserap adalah warna hijau, kuning dan jingga yang memiliki panjang gelombang 500-610 nm. Kurva hasil pengujian sampel indikator dalam berbagai $\mathrm{pH}$ dapat dilihat lebih lengkap pada Gambar 5.

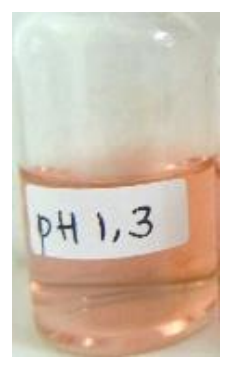

(1)

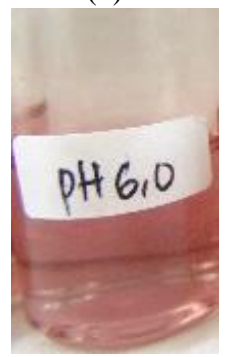

(6)

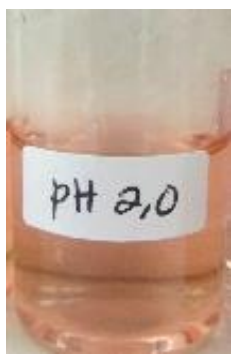

(2)

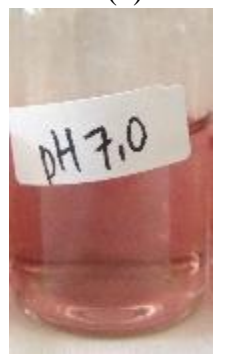

(7)

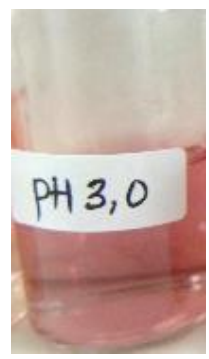

(3)

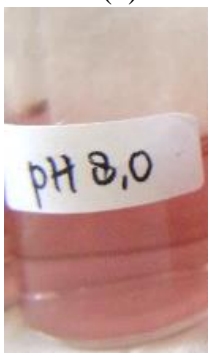

(8)

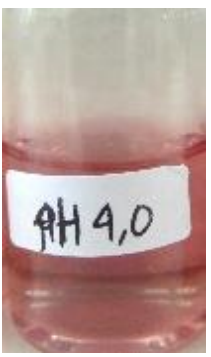

(4)

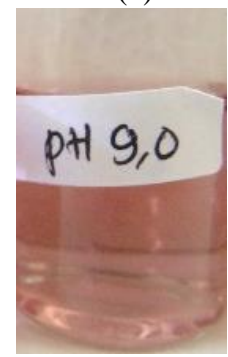

(9)

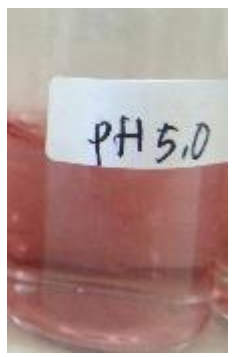

(5)

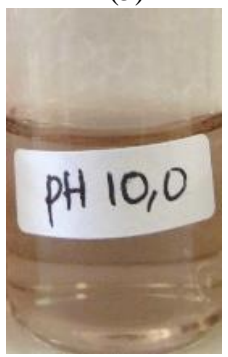

(10)

Gambar 3. Sampel indikator pada $\mathrm{pH} \pm 0,5$ pada perubahan warna $\mathrm{pH}$ kemungkinan trayek $\mathrm{pH}(1,2) \mathrm{ungu},(3)$ ungu kecoklatan, (4) hijau kecoklatan 


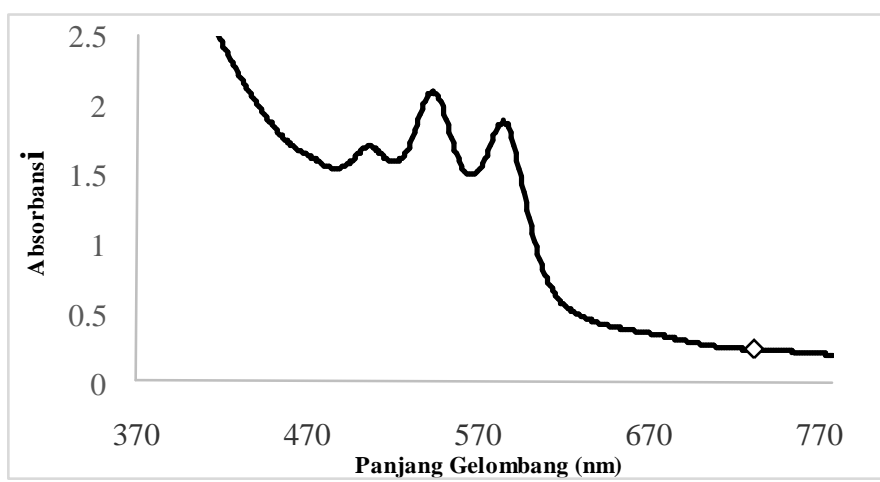

Gambar 4. Panjang gelombang vs absorbansi dari sampel indikator

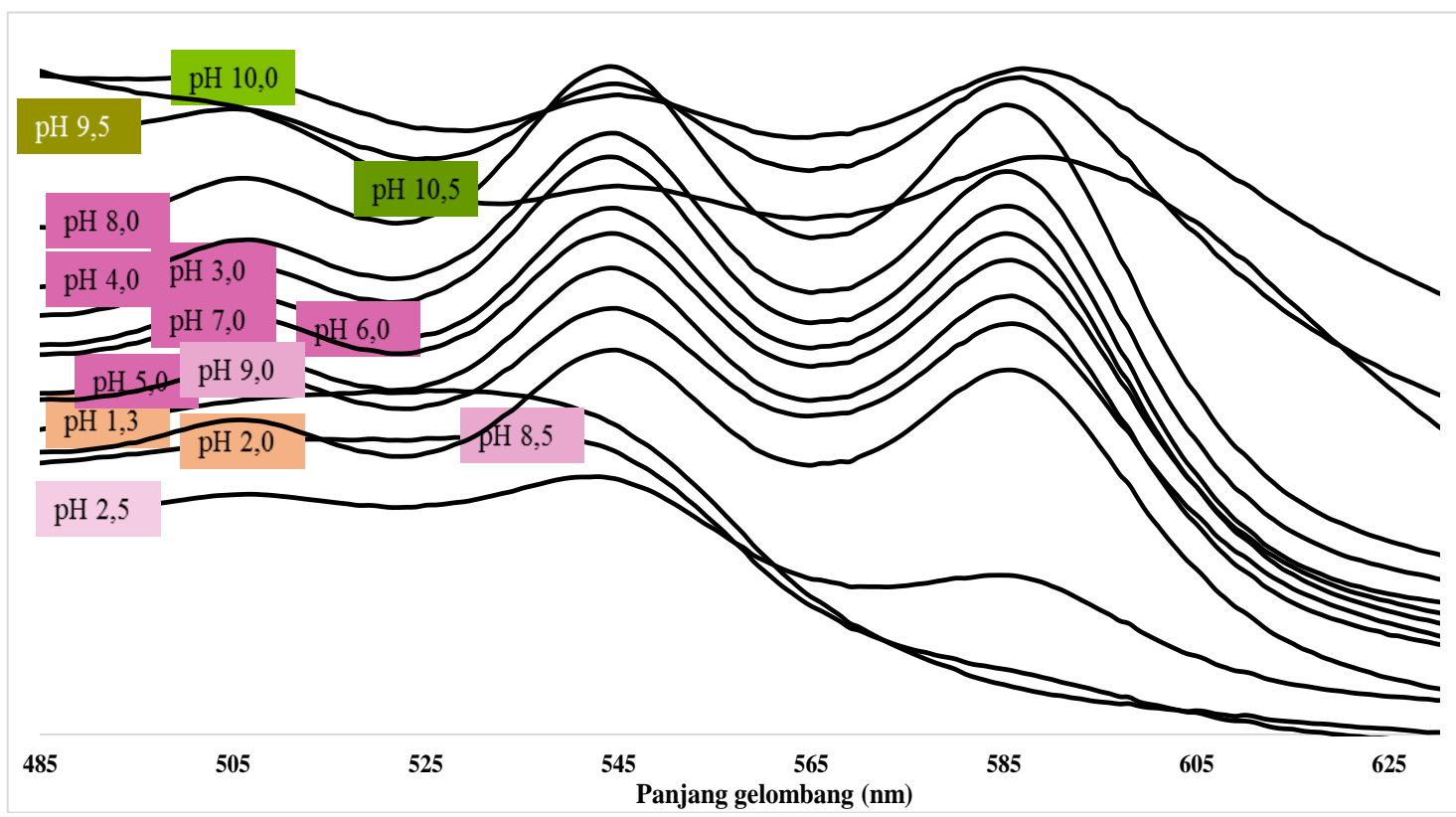

Gambar 5. Spektrum pergeseran panjang gelombang ekstrak indikator daun adam hawa

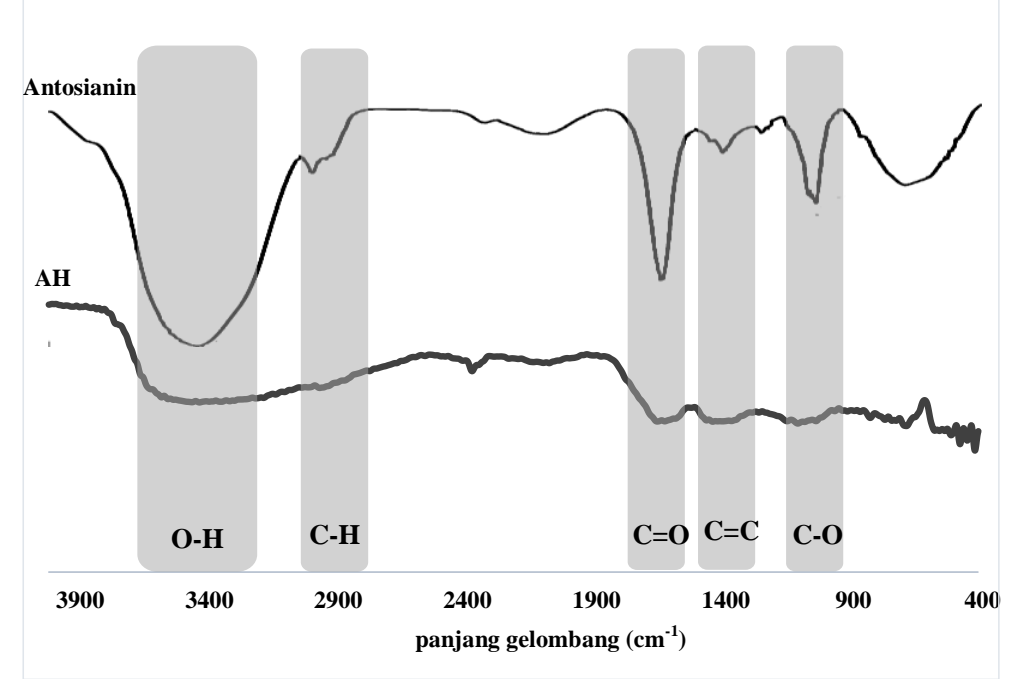

Gambar 6. Spektrum FTIR antosianin dan ekstrak daun adam hawa (AH) 
Tabel 1. Hasil Interpretasi spektrum FTIR sampel dan literatur (Bai et al., 2014; Chandra et al., 2014; Chang et al., 2013)

\begin{tabular}{ccccll}
\hline \multirow{2}{*}{ No } & \multicolumn{2}{c}{ Bilangan Gelombang $\left(\mathrm{cm}^{-1}\right)$} & $\begin{array}{c}\text { Bentuk } \\
\text { Pita }\end{array}$ & Gugus Fungsi & \multicolumn{1}{c}{ Ket } \\
\cline { 2 - 5 } & Antosianin & & & \\
\hline 1 & 3446,03 & 3418,66 & Tajam & Gugus -OH & $\begin{array}{l}\text { Vibrasi } \\
\text { Regangan }\end{array}$ \\
2 & 2950,97 & 2923,66 & Sedang & Gugus $-\mathrm{CH}_{2}{ }^{-}$ & $\begin{array}{l}\text { Vibrasi } \\
\text { Regangan }\end{array}$ \\
3 & 1614,21 & 1639,61 & Tajam & Gugus $-\mathrm{C}=\mathrm{O}$ & $\begin{array}{l}\text { Vibrasi } \\
\text { Regangan } \\
\text { Vibrasi }\end{array}$ \\
4 & 1428,34 & 1427,14 & Tajam & $\begin{array}{l}\text { Gugus C=C } \\
\text { aromatik }\end{array}$ & $\begin{array}{l}\text { Regangan } \\
\text { Vibrasi }\end{array}$ \\
5 & 1098,52 & 1245,43 & Tajam & $\begin{array}{l}\text { Gugus C-O } \\
\text { alkohol }\end{array}$ & $\begin{array}{l}\text { Regangan } \\
\text { Vibrasi } \\
\text { Bengkokan }\end{array}$ \\
\hline
\end{tabular}

Tabel 2. Data hasil titrasi asidi alkalimetri dengan menggunakan sampel indikator

\begin{tabular}{crrrrrr}
\hline \multirow{2}{*}{ No } & \multicolumn{3}{c}{ Titrasi asidimetri } & \multicolumn{3}{c}{ Titrasi alkalimetri } \\
\cline { 2 - 7 } & $\mathrm{pH}$ awal & $\mathrm{V}(\mathrm{mL})$ & $\mathrm{pH}$ akhir & $\mathrm{pH}$ awal & $\mathrm{V}(\mathrm{mL})$ & $\mathrm{pH}$ akhir \\
\hline 1 & 12,46 & 9,1 & 5,6 & 1,33 & 10,9 & 9,99 \\
2 & 12,52 & 12 & 2,24 & 1,3 & 11,2 & 10,2 \\
3 & 12,55 & 10,3 & 2,76 & 1,38 & 11,2 & 8,97 \\
4 & 12,55 & 9,2 & 4,61 & 1,27 & 11,2 & 11,11 \\
5 & 12,56 & 9,4 & 4,55 & 1,24 & 12,5 & 11,61 \\
\hline Rata-rata & & 10 & 3,952 & & 11,52 & 10,376 \\
\hline
\end{tabular}

\section{Hasil pengujian menggunakan spektrofotometer FTIR}

Antosianin merupakan senyawa yang mudah rusak pada suhu tinggi. Sampel juga ditambahkan etanol $96 \%$ untuk mengikat sisa air yang terdapat dalam sampel dan menjadikannya lebih mudah menguap.

Pada Gambar 6 dapat dilihat spektrum FTIR antosianin dan ekstrak daun adam hawa (AH). Spektrum sampel indikator daun adam hawa memiliki pola spektrum yang sama dengan antosianin. Perbandingan dan interpretasi dapat dilihat pada Tabel 1.

Ekstrak daun adam hawa $(\mathrm{AH})$ dan antosianin memiliki gugus $\mathrm{C}=\mathrm{O}$ yang tajam yang berarti terdapat gugus kromofor atau gugus kovalen tak jenuh yang memiliki peranan sebagai pembawa warna suatu senyawa. Gugus $-\mathrm{OH}$ yang tajam menunjukkan adanya auksokrom atau gugus jenuh yang terikat pada kromofor yang berperan memberikan warna lebih kuat pada suatu senyawa (Supratman, 2010).

\section{Hasil analisis potensi indikator dengan titrasi asam basa konvensional}

Perubahan warna yang terjadi pada sampel indikator daun adam hawa seperti yang dapat dilihat pada Gambar 7. menunjukkan perubahan warna dari jingga kemerahan-hijau kecoklatan. Pada Tabel 2 dapat dilihat volume titran yang dibutuhkan dalam titrasi yang menggunakan indikator daun adam hawa.
Titik akhir titrasi asidimetri membutuhkan titran $\mathrm{HCl}$ sebanyak $10 \mathrm{~mL}$ sampai terjadi perubahan warna jingga kemerahan dengan $\mathrm{pH}$ 3,952 dan pada titrasi alkalimetri membutuhkan titran $\mathrm{NaOH}$ sebanyak 11,52 mL yang membuat perubahan warna menjadi hijau kecoklatan pada pH 10,376.

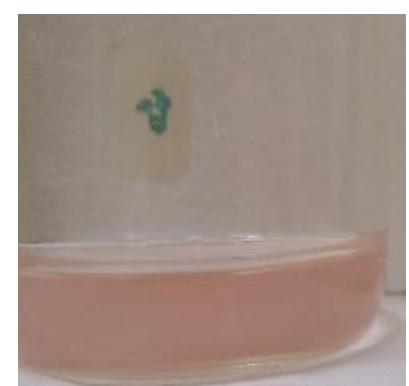

(a)

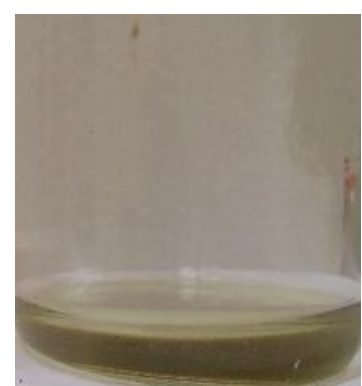

(b)
Gambar 7. Perubahan warna sampel indikator daun adam hawa dalam suasana asam (a) jingga kemerahan dan basa (b) hijau kecoklatan

\section{Hasil analisis perbandingan titrasi dengan} indikator sintetis dan sampel

Pada Tabel 3 dan Tabel 4 dapat dilihat perbandingan titrasi asidimetri alkalimetri dari indikator PP dan MJ dengan sampel indikator daun adam hawa serta nilai persen kesalahan. 
Tabel 3. Persen selisih titrasi asidimetri indikator metil jingga dan sampel indikator

\begin{tabular}{ccccc}
\hline & \multicolumn{2}{c}{ Indikator MJ } & \multicolumn{2}{c}{ Indikator daun adam } \\
No & $\mathrm{V} \mathrm{HCl}$ & $\mathrm{pH}$ & $\mathrm{V} \mathrm{HCl}$ & $\mathrm{pH}$ \\
& $(\mathrm{mL})$ & akhir & $(\mathrm{mL})$ & akhir \\
\hline 1 & 10,70 & 3,50 & 10,30 & 4,60 \\
2 & 10,80 & 3,45 & 11,30 & 2,24 \\
3 & 10,70 & 3,55 & 10,80 & 2,76 \\
4 & 10,90 & 3,47 & 11,50 & 4,61 \\
5 & 10,90 & 3,54 & 10,60 & 4,55 \\
\hline Rata- & 10,80 & 3,502 & 10,90 & 3,752 \\
rata & & & & \\
\hline \multicolumn{5}{c}{} \\
\hline
\end{tabular}

Tabel 4. Persen selisih titrasi alkalimetri indikator fenolftalein dan sampel indikator

\begin{tabular}{|c|c|c|c|c|}
\hline \multirow{2}{*}{ No } & \multicolumn{2}{|c|}{ Indikator PP } & \multicolumn{2}{|c|}{$\begin{array}{c}\text { Indikator daun adam } \\
\text { hawa }\end{array}$} \\
\hline & $\begin{array}{l}\mathrm{V} \mathrm{NaOH} \\
(\mathrm{mL})\end{array}$ & $\begin{array}{l}\mathrm{pH} \\
\text { akhir }\end{array}$ & $\begin{array}{l}\mathrm{V} \text { NaOH } \\
(\mathrm{mL})\end{array}$ & $\begin{array}{l}\mathrm{pH} \\
\text { akhir }\end{array}$ \\
\hline 1 & 10,90 & 9,30 & 11,20 & 9,99 \\
\hline 2 & 10,80 & 9,25 & 10,70 & 10,2 \\
\hline 3 & 11,00 & 9,40 & 11,10 & 8,97 \\
\hline 4 & 10,90 & 9,31 & 11,00 & 10,59 \\
\hline 5 & 11,00 & 9,39 & 11,10 & 10,45 \\
\hline \multirow[t]{2}{*}{$\begin{array}{r}\text { Rata- } \\
\text { rata }\end{array}$} & 10,92 & 9,33 & 11,02 & 10,04 \\
\hline & $\mathrm{Q} \%$ & & $0,915 \%$ & \\
\hline
\end{tabular}

Pada titrasi asidimetri, volume rata-rata $\mathrm{HCl}$ yang dibutuhkan sampai tercapai titik akhir pada titrasi dengan menggunakan indikator $\mathrm{MJ}$ dan indikator $\mathrm{AH}$ masing-masing $10,80 \mathrm{~mL}$ dan $10,90 \mathrm{~mL}$ dengan $\mathrm{pH}$ 3,502 dan 3,752 dengan persen kesalahan (Q\%) sebesar $0,925 \%$, sedangkan pada titrasi alkalimetri, volume rata-rata $\mathrm{NaOH}$ yang dibutuhkan sampai tercapai titik akhir dengan menggunakan indikator PP dan indikator $\mathrm{AH}$ masing-masing $10,92 \mathrm{~mL}$ dan 11,02 mL dengan $\mathrm{p} \mathrm{H9,33}$ dan 10,04 dengan persen kesalahan $(\mathrm{Q} \%)$ sebesar $0,915 \%$.

\section{Hasil analisis penentuan titik ekuivalen titrasi dengan autotitrator}

Dalam penelitian ini, autotitrator digunakan untuk menentukan banyaknya volume titran yang dibutuhkan untuk mencapai titik ekuivalen dan $\mathrm{pH}$ dalam keadaan setimbang karena titik ekuivalen sangat sulit diamati dengan kasat mata.

Kurva titrasi asidimetri dan alkalimetri dengan menggunakan sampel indikator daun adam hawa dapat dilihat pada Gambar 8. Titik ekuivalen (TE) yang ditunjukkan pada titrasi asidimetri terdapat pada pH 7,989; sedangkan TE yang ditunjukkan dalam titrasi alkalimetri ada tiga titik yaitu pada $\mathrm{pH} 4,664$; 6,515 dan 7,456. Hasil autotirator menunjukkan jumlah titran $\mathrm{HCl}$ yang diperlukan untuk mencapai TE adalah sebanyak $11,77221 \mathrm{~mL}$ dan pada titrasi alkalimetri dibutuhkan $\mathrm{NaOH}$ sebanyak $\pm 10,65-11$ $\mathrm{mL}$. Pada titrasi konvensional diperlukan titran $\mathrm{HCl}$ sebanyak 10,90 mL dan titran $\mathrm{NaOH}$ sebanyak 11,02 $\mathrm{mL}$.

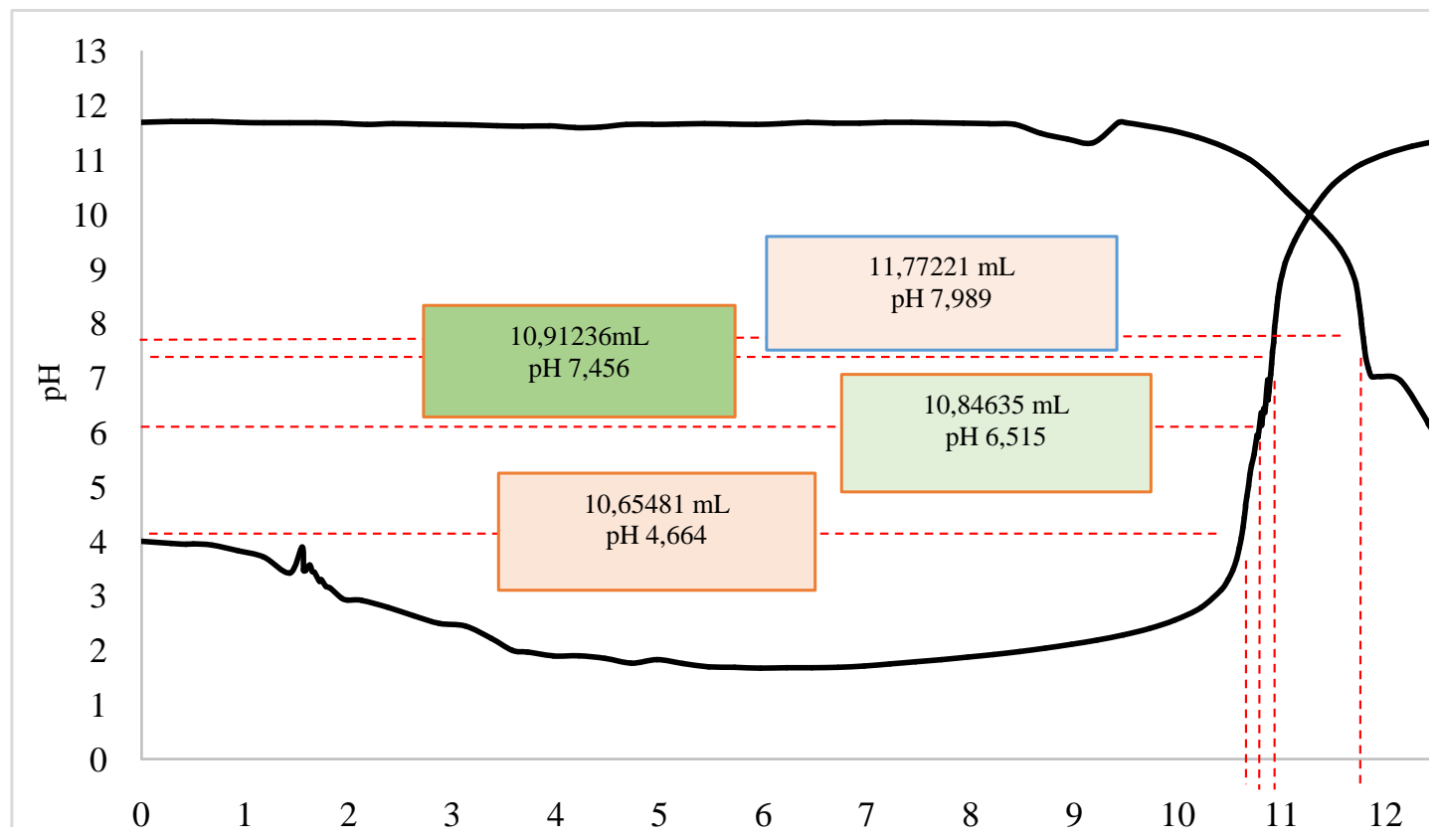

Gambar 8. Kurva titrasi asidimetri dan alkalimetri dengan menggunakan sampel indikator 


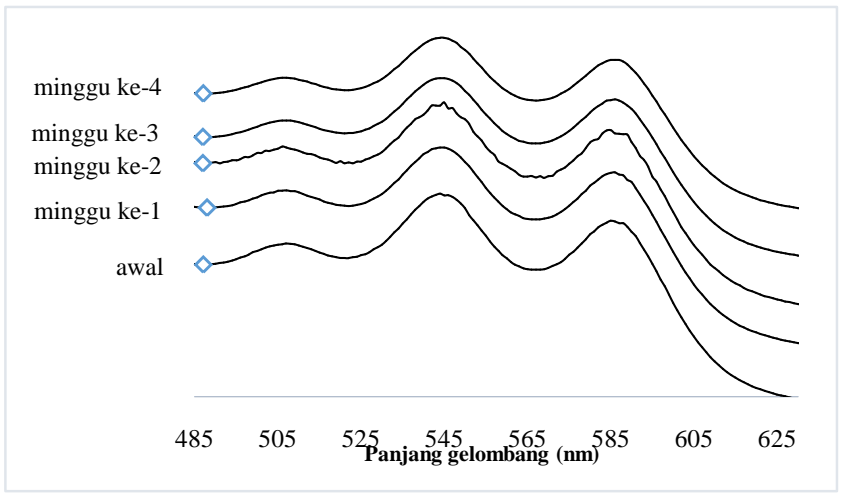

Gambar 9. Spektrum ekstrak indikator selama empat minggu

\section{Hasil pengujian waktu simpan ekstrak daun adam hawa}

Setelah dilakukan pengujian potensi indikator dalam titrasi asidi alkalimetri, untuk mengetahui sejauh mana sampel indikator masih dapat digunakan dalam titrasi, maka dilakukan pengujian waktu simpan selama empat minggu. Pengujian yang dilakukan yaitu dengan mengukur absorbansi sampel indikator dan penggunaan dalam titrasi asidialkalimetri secara konvensional setiap satu minggu sekali selama empat-minggu.

Pada Gambar 9, sampel indikator daun adam hawa menunjukkan tidak terjadi pergeseran panjang gelombang yang signifikan pada pola serapan dari minggu pertama sampai minggu keempat.

Pada Tabel 5 dapat dilihat data hasil titrasi selama empat minggu dengan menggunakan sampel indikator daun adam hawa. Hasil yang ditunjukkan dalam titrasi asidimetri dan alkalimetri memberikan nilai $\mathrm{pH}$ akhir yang masih dekat dan tidak berbeda jauh. Selain itu, secara kasat mata tidak ada perubahan warna yang ditunjukkan oleh sampel indikator adam hawa pada saat digunakan setelah empat minggu.

Tabel 5. Data hasil titrasi menggunakan sampel indikator selama empat minggu

\begin{tabular}{ccccc}
\hline \multirow{2}{*}{$\begin{array}{c}\text { Minggu } \\
\text { ke- }\end{array}$} & \multicolumn{2}{c}{ Titrasi asidimetri } & \multicolumn{2}{c}{ Titrasi alkalimetri } \\
\cline { 2 - 5 } & $\mathrm{V}(\mathrm{mL})$ & $\mathrm{pH}$ akhir & $\begin{array}{c}\mathrm{V} \\
(\mathrm{mL})\end{array}$ & $\mathrm{pH}$ akhir \\
\hline 1 & 12,46 & 3,66 & 11,2 & 9,638 \\
2 & 14,6 & 4,452 & 10,08 & 9,838 \\
3 & 10,7 & 2,332 & 10,94 & 10,124 \\
4 & 10,32 & 2,302 & 12,38 & 10,466 \\
\hline Rata-rata & 12,02 & 3,1865 & 11,15 & 10,0165 \\
\hline
\end{tabular}

\section{Hasil Penentuan trayek pH}

Data serapan panjang gelombang maksimum sampel dan pergeseran panjang gelombang maksimum digunakan untuk menentukan trayek $\mathrm{pH}$ dengan menggunakan nilai selisih absorbansi dan pegeseran dari $\lambda$ max. Trayek $\mathrm{pH}$ dapat dikatakan memiliki nilai \pm 1 dari nilai pKa. Pada Tabel 6 dapat dilihat data penentuan trayek $\mathrm{pH}$ dari sampel indikator daun adam hawa.

Tabel 6. Data penentuan trayek $\mathrm{pH}$ sampel indikator.

\begin{tabular}{ccccc}
\hline $\mathrm{pH}$ & $\begin{array}{r}\lambda \text { max } \\
(\mathrm{nm})\end{array}$ & selisih & Absorbansi & selisih \\
\hline 1,3 & 527,01 & - & 0,2113 & - \\
2,0 & 535,00 & 7,99 & 0,2021 & 0,0092 \\
2,5 & 543,01 & 8,01 & 0,1469 & 0,0552 \\
3,0 & 543,99 & 0,98 & 0,2795 & 0,1326 \\
4,0 & 543,99 & 0 & 0,2861 & 0,0066 \\
5,0 & 591,99 & 48 & 0,2397 & 0,0464 \\
6,0 & 543,99 & 48 & 0,2692 & 0,0295 \\
7,0 & 543,99 & 0 & 0,2517 & 0,0175 \\
8,0 & 543,99 & 0 & 0,3190 & 0,0673 \\
8,5 & 545,00 & 1,01 & 0,2292 & 0,0898 \\
9,0 & 543,99 & 1,01 & 0,2298 & 0,0006 \\
9,5 & 587,01 & 43,02 & 0,2636 & 0,0338 \\
10,0 & 587,01 & 0 & 0,2180 & 0,0456 \\
10,5 & 510,01 & 77 & 0,3418 & 0,1238 \\
\hline
\end{tabular}

Indikator ekstrak daun adam hawa memiliki $\lambda$ maksimum yang bervariasi. Pada $\mathrm{pH} 1,3$ dan 2,0 $\lambda$ maksimumnya adalah 527,01 dan 535,00 nm dengan pergeseran 7,99. Hal ini terjadi karena pada $\mathrm{pH}$ tersebut memiliki warna komplementer yang sama yaitu jingga. Pada $\mathrm{pH}$ 2,5-9,0 sebagian besar $\mathrm{pH}$ menunjukkan $\lambda$ maksimum pada $543,99 \mathrm{~nm}$, namun pada $\mathrm{pH}$ 5,0 dan $\mathrm{pH} 8,5$ masing-masing memiliki $\lambda$ maksimum 591,99 dan $545 \mathrm{~nm}$ karena pada $\mathrm{pH}$ ini warna larutan memiliki warna yang lebih pekat dibandingkan pada $\mathrm{pH}$ 2,5-9,0. Panjang gelombang maksimum pada $\mathrm{pH} 9,5$ dan 10,0 adalah $587,01 \mathrm{~nm}$ dan pergeseran $\lambda$ maksimum paling besar terjadi pada 
Tabel 7. Perbandingan nilai trayek $\mathrm{pH}$ dan titik ekuivalen sampel

\begin{tabular}{ccccc}
\hline Titrasi & V titrasi konv. $(\mathrm{mL})$ & Trayek $\mathrm{pH}$ & $\mathrm{V}$ autotitrator $(\mathrm{mL})$ & $\mathrm{TE}$ \\
\hline Alkalimetri & 10,90 & $4,75-6,75$ & 11,7722 & 7,989 \\
\hline \multirow{3}{*}{ Asidimetri } & \multirow{2}{*}{11,02} & & 10,6514 & $1=4,66$ \\
& & $4,75-6,75$ & 10,8463 & $2=6,51$ \\
& & & 10,9123 & $3=7,98$ \\
\hline
\end{tabular}

$\mathrm{pH} \quad 10,5$ dengan pergeseran 77 pada panjang gelombang $510,01 \mathrm{~nm}$. Ketiga $\mathrm{pH}$ ini memiliki warna coklat yang semakin menghijau pada $\mathrm{pH}$ 10,5. Pergeseran $\lambda$ maksimum yang paling signifikan pada sampel indikator daun adam hawa ada pada $\mathrm{pH} 2,5-$ 9,0 didapatkan titik tengahnya yang merupakan $\mathrm{pKa}$ dari sampel indikator daun adam hawa yaitu pada $\mathrm{pH}$ 5,75. Hasil analisis menunjukkan, trayek $\mathrm{pH}$ sampel indikator daun adam hawa adalah pada kisaran $\mathrm{pH}$ 4,75-6,75.

Secara visual ekstrak daun adam hawa berpotensi sebagai indikator titrasi asam basa, karena telah memenuhi karakteristik indikator yaitu memberikan perubahan warna pada suasana yang berbeda (asam ataupun basa) dengan memiliki warna yang konsisten dalam senyawa yang stabil.

TE sulit diamati tanpa menggunakan instrumen. Nilai dari titik ekuivalen menjadi acuan dari ketepatan dalam penentuan nilai trayek $\mathrm{pH}$ indikator.

Pada Tabel 7 dapat dilihat perbandingan nilai trayek $\mathrm{pH}$ dan titik ekuivalen sampel.

Berdasarkan TE yang ditunjukkan autotitrator memiliki nilai yang berdekatan dengan trayek $\mathrm{pH}$ yang ditentukan melalui perhitungan dari hasil analisis spektrofotometri UV-Vis. Ekstrak daun adam hawa cukup baik digunakan sebagai indikator titrasi asam basa untuk menggantikan indikator sintetis.

\section{KESIMPULAN}

1. Indikator ekstrak daun adam hawa berpotensi sebagai indikator titrasi asam dan basa.

2. Indikator ekstrak daun adam hawa memiliki trayek pH4,75-6,75 dengan perubahan warna dari jingga kemerahan-hijau kecoklatan.
3. Persen selisih $(\% \mathrm{Q})$ titrasi indikator ekstrak daun adam hawa dengan indikator sintetis pada titrasi asam dan basa masing-masing menunjukkan nilai $0,925 \%$ dan $0,915 \%$.

\section{DAFTAR PUSTAKA}

Bai, H., Wang, Z., Cui, J., Yun, K., Zhang, H., Liu, R.H., Fan, Z. \& Cheng, C. (2014). Synergistic Radiation Protective Effect of Purified Auricularia auricular-judae Polysaccharide (AAP IV) with Grape Seed Procyanidins, Molecules, 19(12): 20675 - 20694.

Day, R.A. \& Underwood, A.L. (1986). Analisis Kimia Kuantitatif. Jakarta: Erlangga.

Chang, H., Kao, M.-J., Chen, T.-L., Chen, C.-H., Cho, K.-C. \& Lai, X.-R. (2013). Characterization of Natural Dye Extracted from Wormwood and Purple Cabbage for DyeSensitized Solar Cells, International Journal of Photoenergy, 1-8.

Kadir, A. (2008). Tanaman Hias Bernuansa Varigata. Yogyakarta: Lily Publisher

Winarno, F.G. (1992). Kimia Pangan dan Gizi. Edisi Keenam. Jakarta: Gramedia.

Chandra, S., Pradhan, S., Mitra, S., Patra, P., Bhattacharya, A., Pramanik, P. \& Goswami, A. (2014). High throughput electron transfer from carbon dots to chloroplast: a rationale of enhanced photosynthesis, Nanoscale, 6(7), $3647-3655$

Supratman, U. (2010). Elusidasi Struktur Senyawa Organik. Bandung: Widya Padjadjaran. 